\title{
Solid pseudopapillary neoplasia of the pancreas: a review
}

\author{
Vera Lucia Chagas' \\ Fernando Colonna Rosman ${ }^{2}$ \\ Maria da Gloria da Costa Carvalho 3
}

\begin{abstract}
1. Professora no Departamento de Patologias, Faculdade de Medicina do Hospital Clementino Fraga Filho da Universidade Federal do Rio de Janeiro, Rio de Janeiro, RJ, Brasil

2. Professor do Departamento de Patologias, Faculdade de Medicina do Hospital Clementino Fraga Filho da Universidade Federal do Rio de Janeiro, Rio de Janeiro, RJ, Brasil

3. Pesquisadora no Departamento de Patologias, Faculdade de Medicina do Hospital Clementino Fraga Filho da Universidade Federal do Rio de Janeiro, Rio de Janeiro, RJ, Brasil
\end{abstract}

http://dx.doi.org/10.1590/1806-9282.66.1.87

\section{SUMMARY}

OBJECTIVES: To review the literature and the diagnosis of conventional histopathological routine and immunohistochemistry of the cases diagnosed with Solid Pseudopapillary Neoplasm of the Pancreas (SPNP).

METHODS: The review of the literature was done using the Pubmed and solid Google-Scholar databases, through the historical, clinical aspects and diagnostic methods of SPNP. The review of SPNP cases diagnosed in the University Hospital Clementino Fraga Filho was carried out from 1977 to 2018.

RESULTS: Intratumoral phenotypic heterogeneity of SPNP was evidenced in the cases studied, taking into account macroscopic, microscopic, and immunohistochemical patterns.

CONCLUSIONS: The results show the importance of the examination of several fragments obtained from different regions of the neoplasia since not all of them present the same molecular alterations.

KEYWORDS: Pancreas. Solid Pseudopapillary Neoplasia.

\section{INTRODUCTION}

Solid pseudopapillary neoplasm of the pancreas is a rare tumor, with low potential of malignancy, of uncertain lineage, and favorable prognosis in most cases $^{1}$. It has received different denominations, including "Frantz tumor", "cystic solid tumor", "papillary cystic tumor", "papillary epithelial neoplasia”, among others. In 1996, it was defined by the WHO as a "solid pseudopapillary tumor" for the international histological classification of pancreas tumors ${ }^{1}$. That name covers the most distinct macroscopic and microscopic aspects of the neoplasia, i.e., solid and pseudopapillary. It represents around 1-3\% of all exocrine pancreatic neoplasias ${ }^{3}$. It is most frequent in women $(82 \%)$ of all ages. It is usually asymptomatic, but sometimes a palpable mass, pain, and abdominal discomfort, and 
nausea can be observed ${ }^{5 .}$ It is characterized by a solid-cystic growth pattern with pseudopapillary structures. Surgical resection is the treatment of choice and provides a good prognosis, even when there is distant metastasis or recurrence ${ }^{1,6}$. The is no apparent ethnic predilection or any association with known clinical or genetic syndromes, although some rare cases have been reported in patients with familial adenomatous polyposis (FAP) ${ }^{7}$. Due to its rarity, the clinical data regarding these tumors are, most often, limited to case reports or small series, especially in the Asian population ${ }^{7}$. However, the diagnosis for SPNP has been more frequent due to the awareness regarding its existence, to the more widespread use of immunohistochemical methods, and retrospective studies on tumors that were not properly identified $^{8}$.

Despite several studies using electron microscopy and immunohistochemistry, the cell origin of this neoplasia remains uncertain. Several researchers favor the hypothesis of a multipotential primitive cell as an origin, particularly due to the absence of a predominant line of differentiation and the multidirectional differentiation found ${ }^{9}$. In a recent study of 14 SPNP pediatric patients, no evidence was found of the PDX1, SOX9, PTF1A, and NKX2.2 transcription factors associated with pancreatic development ${ }^{10}$. An extrapancreatic origin has been suggested by some authors ${ }^{6}$ due to several cases of a reported presence of primary tumors in different areas of the pancreas, such as the ectopic pancreas ${ }^{11}$, retroperitoneum ${ }^{12}$, gastroduodenal area ${ }^{13}$, and ovary ${ }^{14}$. The origin of the primitive cells in the genital system, over a pancreatic origin, has been considered by some authors ${ }^{15}$.

\section{CLINICAL ASPECTS}

Solid pseudopapillary neoplasm of the pancreas is usually detected incidentally on routine physical examinations or abdominal imaging exams performed for various reasons ${ }^{3}$. The signs and symptoms are nonspecific and related to the intra-abdominal mass, including pain, dyspepsia, early satiety, nausea, and vomiting ${ }^{1}$. Jaundice is rare, even when the tumor is located at the head of the pancreas. The serological tumor markers are normal, and there is no description of association with functional endocrine syndromes ${ }^{5}$. Since surgical resection is usually curative, in most cases, and recurrences can be treated surgically, it is important to have an accurate diagnosis ${ }^{6}$. SPNP should be considered in the differential diagnosis of any solid or partially cystic mass, located in the pancreas or in the upper abdomen, mainly in young women ${ }^{16}$.

In computed tomography, magnetic resonance, and ultrasound, the neoplasm is often well-circumscribed, encapsulated and heterogeneous, often with cystic and hemorrhagic areas and, at times, with calcifications ${ }^{17}$. The preoperative diagnosis can be established by means of fine-needle biopsy guided by endoscopic ultrasound (echoendoscopy). Echoendoscopy became very useful to assess pancreatic lesions observed in other imaging exams or when there is a suspicion of such injury based on clinical and laboratory examinations. The exam is generally safe and can be performed in most cases, and the material obtained must be evaluated by the cytopathologist through smears or cell blocks (cell block). The results allow for a treatment based on the diagnoses obtained. Its use allows surgeons and oncologists to have more appropriate planning for the patient's approach ${ }^{18}$.

\section{ANATOMOPATHOLOGICAL DIAGNOSIS}

SPNP can occur in any region of the pancreas, and, in general, one third occurs in the head, one third in the body, and another third on the tail. Macroscopic examination shows masses that vary from $0.5 \mathrm{~cm}$ to $25.0 \mathrm{~cm}$ in diameter (mean diameter of $8-10 \mathrm{~cm}$ ). In general, they are rounded, well-circumscribed, and separated from the pancreatic parenchyma by a fibrous pseudocapsule; however, under microscopy, neoplastic cells can be seen infiltrating the pancreatic parenchyma, permeating acini, and pancreatic islets ${ }^{5}$. The cut surface shows variable appearance, with yellowish or brownish solid areas, hemorrhagic foci, or cystic degeneration filled with necrotic debris ${ }^{5,8}$. Smaller tumors tend to be more robust than those of larger diameter, and hemorrhagic-cystic areas, when extensive, may suggest a pseudocyst. They rarely spread to the stomach, the duodenum or to the spleen, and metastases occur in 5-15\% of cases, mainly to the liver and peritoneum. The staging follows that of other pancreatic carcinomas ${ }^{5}$.

The microscopic appearance of SPNP is heterogeneous, with a varied proportion of solid, pseudopapillary, hemorrhagic, and pseudocystic areas, representing the solid and cystic natures of the neoplasm ${ }^{5,8}$. The solid areas, located mainly in the periphery of the tumors, when these are notably 
hemorrhagic-cystic, are formed by little cohesive cells, polygonal, monomorphic, with eosinophilic cytoplasm, or with a light or spumous appearance, separated by delicate blood vessels amidst a variable amount of perivascular collagen ${ }^{5,8}$. The pseudopapillary tumors are formed by the degeneration of the little-cohesive cells, leaving those who are closest to the conjunctive-vascular axis. These cells are frequently located perpendicularly to the axis, leaving the core in the apical position. The nuclei are rounded or oval, with disperse chromatin, and, at times, have longitudinal folds. Mitoses are rare (average of 0 to 10 in 50 fields of large magnification). Some of the neoplastic cells contain intracytoplasmic eosinophilic globules, positive to staining by PAS (Periódico-Schiff Acid), after digestion with diastole; these globules can also be found in the extracellular medium. Foci of calcification, foreign-body giant cells containing cholesterol crystals, and bizarre nuclei can also be observed ${ }^{5}$. Cellular pleomorphism and cell atypia are not common but have been reported, mainly in the more aggressive forms of neoplasia ${ }^{19}$. Perineural invasion, angioinvasion, and infiltration of the adjacent pancreatic parenchyma do not indicate a more aggressive behavior, since SPNPs without these characteristics can metastasize, which is why all these tumors are, therefore, classified as low-malignant neoplasms ${ }^{5}$.

\section{IMMUNOHISTOCHEMISTRY}

Histologically, the SPNP phenotype does not resemble any of the pancreatic epithelial cells ${ }^{8}$, but its histological appearance is very characteristic and, in most cases, can provide a diagnosis; immunohistochemistry is used to confirm the diagnosis or, in some cases, to assist in the differential diagnosis ${ }^{20}$. A aberrant, nuclear, and cytoplasmic positive response to beta-catenin, the loss of membrane expression of E-cadherin ${ }^{20}$, the characteristic perinuclear granular intracytoplasmic marking (dot-like) to CD9921, associated with a positive response to the progesterone receptor ${ }^{20}, \mathrm{CD} 10$ and $\mathrm{CD} 56^{22}$ constitute a basic immunohistochemical scenario for the histopathologic diagnosis of SPNP. In a study with 19 SPNPs, markers such as cytokeratins and alpha- 1 antitrypsin were expressed in varying degrees, and chromogranin A had no expression ${ }^{22}$. The expression of Ki- 67 in the usual forms of neoplasia is usually low; however, in aggressive forms, it can reach $50 \%$ of positivity ${ }^{19}$.

\section{DIFFERENTIAL DIAGNOSIS}

The histopathological diagnosis for this tumor is sometimes difficult, since its histomorphology and immunophenotype may suggest other exocrine and endocrine pancreatic tumors ${ }^{7}$. When in the SPNP there is a predominance of solid areas or light cells, or when there are pseudopapillary areas in neuroendocrine tumors, the immunohistochemical study is essential for the differential diagnosis, especially in specimens obtained by needle biopsy ${ }^{20}$. The solid pattern resembles that of acinar cell carcinoma and neuroendocrine tumor, while the cystic aspect is observed in pancreatic adenocarcinomas and neuroendocrine tumors. This should be the primary neoplasm to be excluded in the differential diagnosis, because in addition to the morphological similarity, the solid pseudopapillary pancreatic neoplasia can express some neuroendocrine markers in the immunohistochemistry, such as CD56, neuron-specific enolase, progesterone receptor and, more rarely, synaptophysin. However, the nuclear expression of beta-catenin, the loss of membrane E-cadherin, positive CD10, associated with the absence of chromogranin and perinuclear granular expression of CD99 favor the diagnosis of SPNP, 3,,20,21.

\section{MOLECULAR PATHOLOGY}

Molecular analysis of SPNPs shows that they are distinct from pancreatic adenocarcinomas. Changes in genes KRAS, CDKN2A/p16, TP53, and SMAD4/DPC4, often present in the ductal carcinoma, have not been observed in SPNPs; however, almost all SPNPs feature somatic point mutations in exon 3 of CTNNB1, the gene that encodes beta-catenin ${ }^{23}$. These mutations are related to the activation of the $\mathrm{Wnt} / \beta$-catenin signaling pathway, preventing the intracytoplasmic phosphorylation and the subsequent degradation of the beta-catenin protein, which then accumulates in the nucleus of neoplastic cells. As a result, $90 \%$ of SPNPs present an abnormal pattern of nuclear marking of the beta-catenin protein, while in the healthy pancreas, the marking is on the membrane. This nuclear accumulation of beta-catenin stimulates the transcription of several genes, such as $c-m y c$ and cyclin D1, both involved in cell proliferation ${ }^{23}$. In addition, $\beta$-catenin interacts with E-cadherin, so that the deregulation of the first also interferes in the expression of the second, and, as a consequence, no E-cadherin membrane expression is observed in most SPNPs ${ }^{23}$. The loss of the normal expression of E-cadherin seems to be related 
to the lack of adhesion and cohesion of neoplastic cells among themselves, causing the typical pseudopapillary aspect of this neoplasm, like with the cystic degenerations observed in $\mathrm{it}^{20}$. In a study on methylation in three different areas of the same tumor, Chagas and col. $^{24}$ found methylation of codifying genes of the protein p16 (cyclin-dependent kinase inhibitor 2A) and TIMP-2 (tissue inhibitor of metalloproteinase 2 ) in two areas, indicating a potential for malignancy and heterogeneous progression in this neoplasia due to the inactivation of the expression of these genes. The protein p16 is an important tumor suppressor, reducing cell proliferation and nontissue inactivation of metalloproteinase 2, encouraging the degradation of the extracellular matrix and the invasion and the occurrence of metastases. In a molecular study of three distinct areas of the tumor were identified by mass spectrometry (MS) 1.427, 5.786, and 4.298 proteins, respectively, being 1.337 common to all three fragments, showing the heterogeneity of tumor ${ }^{25}$.

\section{CASES REVIEWED IN 21 YEARS IN THE PATHOLOGICAL ANATOMY SERVICE OF THE UNIVERSITY HOSPITAL CLEMENTINO FRAGA FILHO - UFRJ \\ Methodology}

Were reviewed eight cases of SPNP diagnosed in the period of 21 years (1997-2018), in the HUCFF/ UFRJ, of seven female patients aged between 12 and
46 years (project approved by the CEP HUCFF/UFRJ under CAE No. 64915717.0.0000.5257). We carried out a review of the medical records to retrieve the patients' clinical and evolution information, post-surgery. We observed that the main clinical manifestations reported were abdominal pain, more precisely in the right hypochondrium (three cases), and on the left (one case), nausea, and vomiting. The presence of a palpable abdominal mass was observed in four cases. Three patients whose neoplasias were located in the head of the pancreas were subjected to duodenopancreatectomy (Whipple surgery) and two to body-tail pancreatectomy and splenectomy (neoplasia located in the body-tail region of the pancreas). Three patients were diagnosed by echoendoscopic pancreatic biopsy, and one was later submitted to surgery.

In the review of medical records, we observed that a patient was followed-up on an outpatient basis for four years, another for two years, and a third is still being followed-up (P16 5242), without any complications in this period. In the medical records of four patients, no information was found regarding the period after discharge (Table 1).

The paraffin blocks corresponding to the examinations were obtained from the archive of the Pathology Service, HUCFF/UFRJ, and their respective histological sections were submitted to routine techniques for conventional histopathology and immunohistochemistry assays (Table 2). In one case, a molecular biology assay was conducted $\mathrm{d}^{24,25}$.
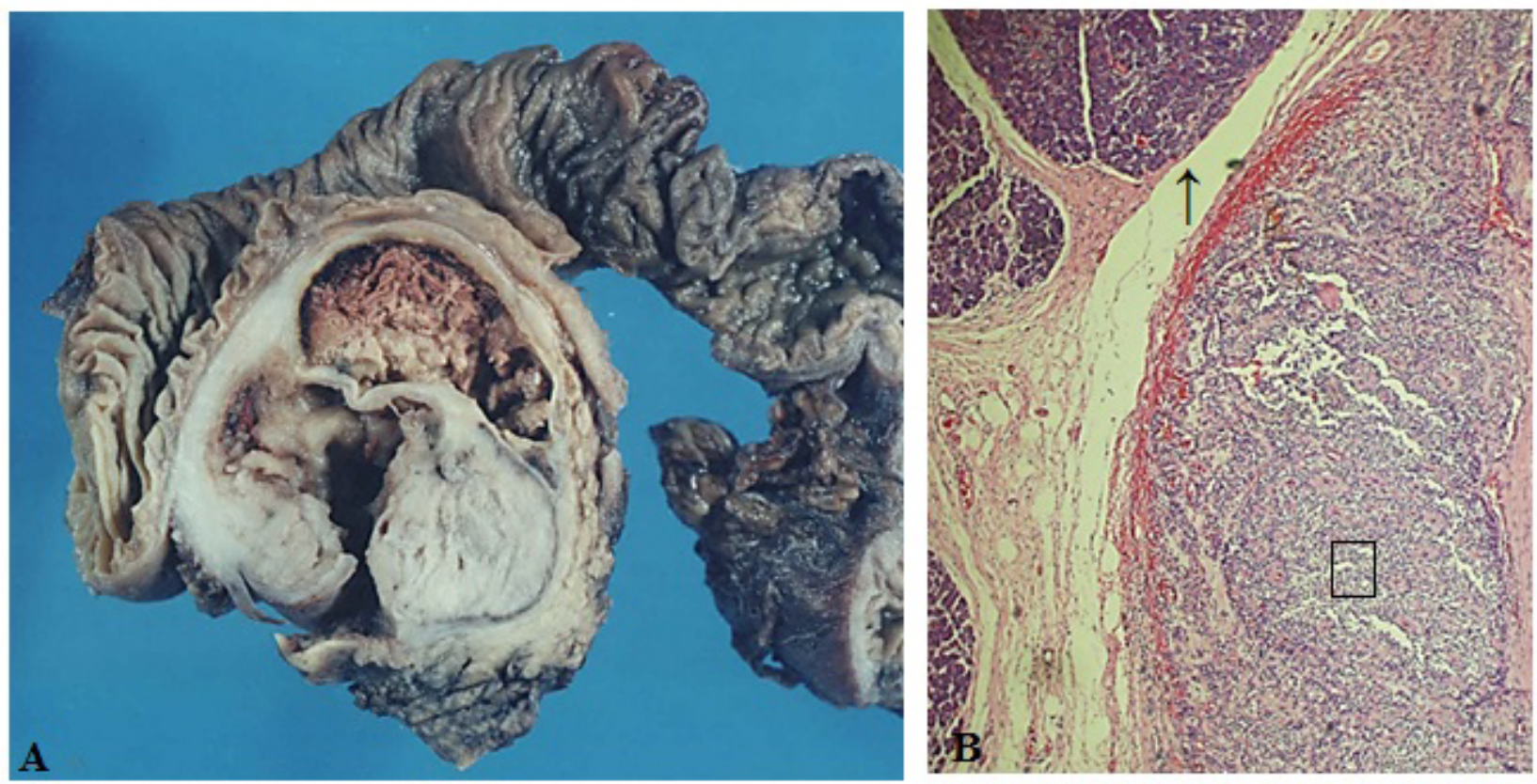

FIGURE 1. 
TABLE 1. CASES REVIEWED IN TWENTY ONE YEARS IN THE ANATOMIC PATHOLOGY SERVICE - HUCFF

\begin{tabular}{|c|c|c|c|c|c|c|}
\hline Biopsy No & Age & Clinic & $\begin{array}{l}\text { Location of } \\
\text { the neoplasia }\end{array}$ & $\begin{array}{l}\text { Dimen- } \\
\text { sions in cm }\end{array}$ & Previous diagnosis & Procedure \\
\hline B2116-97 & 27 & $\begin{array}{l}\text { LH pain, LH palpable } \\
\text { mass }\end{array}$ & Head and body & $10 \times 7 \times 6$ & $\begin{array}{l}\text { Cystadenoma, cystade- } \\
\text { nocarcinoma } \\
\text { a }\end{array}$ & Duodenopancreatectomy \\
\hline P00 3249 & 46 & $\begin{array}{l}\text { LH pain, palpable } \\
\text { mass } \\
\text { LH, vomiting }\end{array}$ & head & $6.5 \times 6 \times 4.5$ & Adenocarcinoma & Duodenopancreatectomy \\
\hline P11 1978 & 14 & $\begin{array}{l}\text { Abdominal pain, } \\
\text { vomiting }\end{array}$ & Body and tail & $2.5 \times 2 \times 2$ & Pancreatoblastoma & $\begin{array}{l}\text { Body/tail pancreatec- } \\
\text { tomy }\end{array}$ \\
\hline C12 1733 & 13 & Abdominal mass & Body and tail & $\mathrm{NI}$ & SPNP & Echoendoscopic biopsy \\
\hline C15 1962 & $\mathrm{NI}$ & Abdominal pain & Body & $\mathrm{NI}$ & SPNP, NET & Echoendoscopic biopsy \\
\hline $\begin{array}{l}\text { C15 } 7785 \text { (C15- } \\
\text { 1962) }\end{array}$ & 23 & $\begin{array}{l}\text { LH pain, nausea, } \\
\text { vomiting }\end{array}$ & Body and tail & $7 \times 4 \times 7$ & $\begin{array}{l}\text { SPNP (previous cytologi- } \\
\text { cal diagnosis) }\end{array}$ & $\begin{array}{l}\text { Body/tail pancreatec- } \\
\text { tomy }\end{array}$ \\
\hline P16 5242 & 12 & $\begin{array}{l}\text { LH pain, LH palpable } \\
\text { mass, vomiting }\end{array}$ & Head & $\begin{array}{l}6 \mathrm{~cm} \text { of } \\
\text { diameter }\end{array}$ & To be clarified & Duodenopancreatectomy \\
\hline C18 113 & 34 & $\mathrm{NI}$ & Tail & 3 & Mucinous neoplasia & Echoendoscopic biopsy \\
\hline
\end{tabular}

NI - no informatiion; LH; left hypochondrium; SPNP -solid pseudopapillary neoplasm of the pancreas; NET: neuroendocrine tumor ; HUCFF - University Hospital Clementino Fraga Filho

TABLE 2. HISTOPATHOLOGY

\begin{tabular}{|c|c|c|c|c|c|c|c|c|c|c|}
\hline Biopsy No & $\mathrm{EC}$ & PSP & LGT C & AP & DGC & $\mathrm{HE}$ & $\mathrm{F}$ & A & $M$ & C \\
\hline B2116-97 & + & + & ++ & ++ & AEG & + & +++ & + & 0 & $\mathrm{FI}$ \\
\hline P0O 3249 & + & + & ++ & + & $\mathrm{CN}$ & ++ & ++ & - & 2 & $\mathrm{~F}$ \\
\hline P11 1978 & + & + & + & + & $\begin{array}{l}\text { CN; C; } \\
\text { GGCCC; GT }\end{array}$ & ++ & ++ & - & 0 & 1 \\
\hline C12 1733 & + & ++ & - & - & - & + & - & + & 0 & ND \\
\hline C15 1962 & + & + & - & - & - & + & - & + & - & ND \\
\hline C15 7785 & + & + & + & + & GGCCC & ++ & ++ & + & 0 & $\mathrm{~F}$ \\
\hline P16 5242 & + & + & + & + & $C V$ & + & - & + & 6 & I \\
\hline C18 113 & + & $+/-$ & - & - & - & + & - & $+1-$ & 0 & ND \\
\hline
\end{tabular}

EC: Eosinophilic cells; PSP: pseudopapillary formation; LGT C: light cells; AP: apoptosis; DGC: degenerative changes HE: hemorrhage ; F: fibrosis; A: atypia (multiple nuclei, increased volume, nucleoli); M: mitosis (10 / large magnification field); C: capsule; AEG: eosinophilic granules; CN: coagulation necrosis; C: calcification; GGCCC: granuloma with giant cells and cholesterol crystals; GT: granulation tissue; CV: cellular vacuolation; FI: fibrous invasion; F: fibrosis; I: invasion; ND: Not determined; + positive; negative -

\section{RESULTS}

The macroscopic examination revealed rounded or oval masses, measuring between $2.5 \times 2 \times 2 \mathrm{~cm}$ and $10 \times 7 \times 6 \mathrm{~cm}$, of a firm and elastic consistency, apparently encapsulated, three located in the head of the pancreas and two in the middle body/tail region of the pancreas. In the sections, it was possible to see clear and regular borders and whitish or yellowish surfaces, with solid areas located mainly in the periphery of the tumor, and areas sometimes grainy, others soft, associated with the hemorrhagic areas (Fig. 1A).

The histopathological examination of the slides stained with hematoxylin and eosin showed isolated neoplasms of the pancreatic parenchyma by fibrous pseudocapsule (Fig. 1B), which was permeated in three cases, but not crossed by neoplastic cells. They were polyedric, little cohesive, with eosinophilic (Fig. 2A) or light (Fig. 2B) cytoplasm, forming cell masses permeated by a delicate connective-vascular stroma. The nuclei were rounded or oval, with regular contours or slightly ribbed, or even with mild anisokaryosis. Cells with hyperchromatic nuclei, sometimes multiple, were present, focally, in one of the cases. The number of mitoses ranged from zero (five cases) to six (one case) in ten fields of large magnification. The neoplastic cells were frequently positioned perpendicularly around the axis, configuring pseudopapillary formations, on which occasion the cytoplasm appeared to be more elongated, and the nuclei were located in the apical edge of the cell 

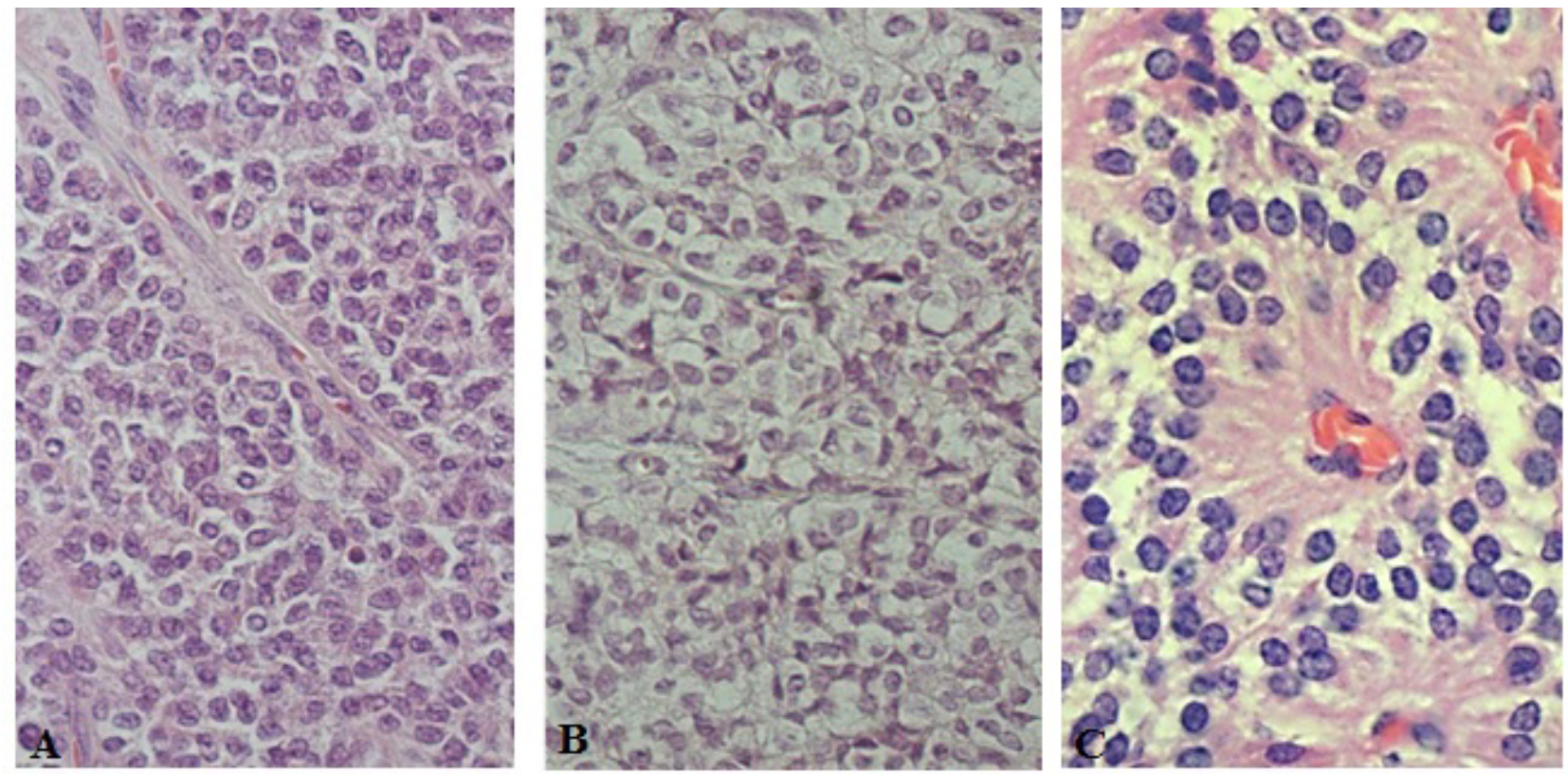

FIGURE 2.
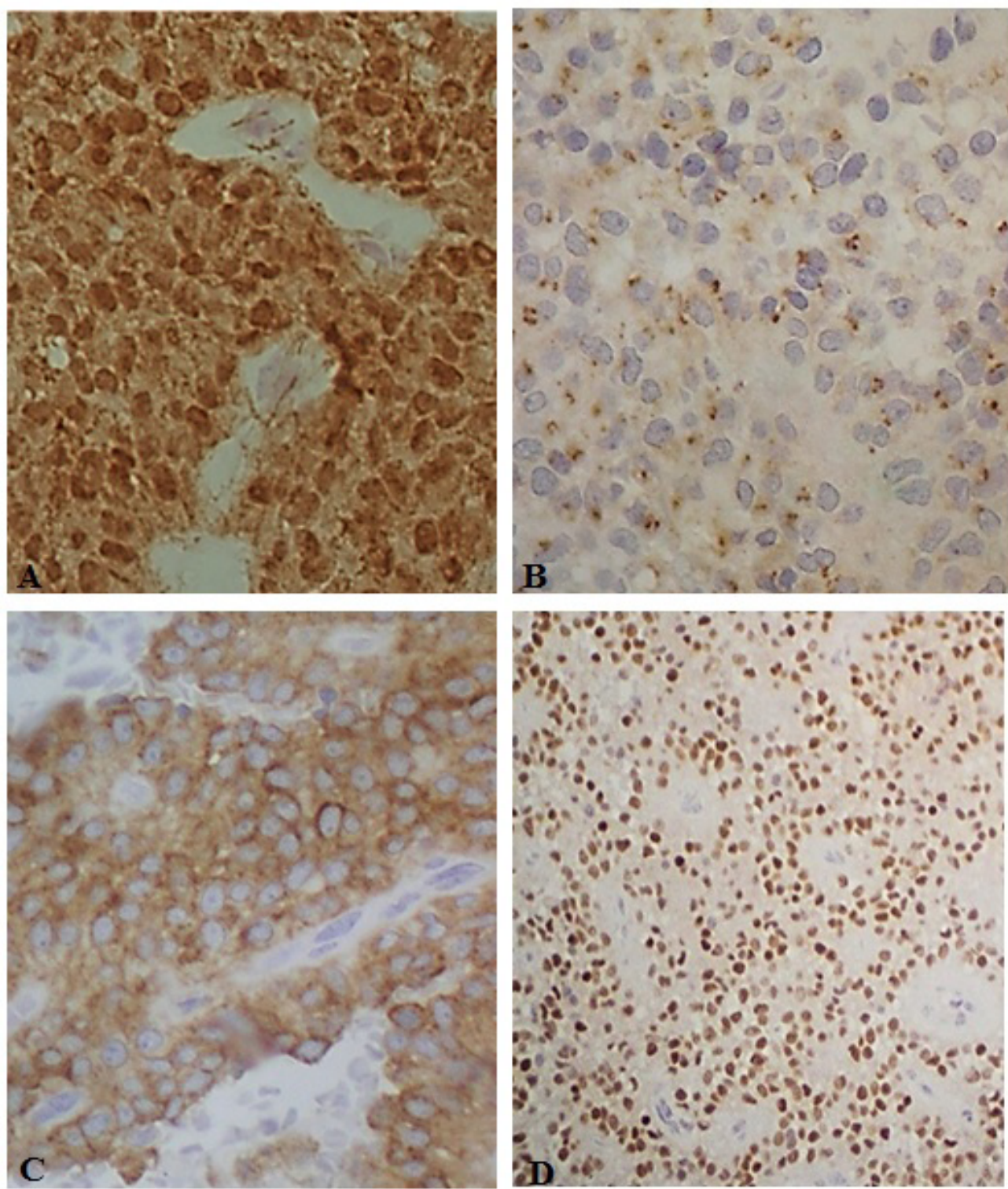

FIGURE 3. 
TABLE 3. IMMUNOHISTOCHEMISTRY

\begin{tabular}{|c|c|c|c|c|c|c|c|c|c|c|}
\hline Biopsy No & B-catenin & CD99 & CD10 & CD56 & $\begin{array}{l}\text { Progesterone } \\
\text { receiver }\end{array}$ & $\begin{array}{l}\text { Chromo } \\
\text { granin }\end{array}$ & $\begin{array}{l}\text { Synapto- } \\
\text { physin }\end{array}$ & Ecaderin & $\mathrm{Ki}-67$ & OBS \\
\hline B2116-97 & NP & POS & POS & $N P$ & POS & NEG & NEG & NP & $<2 \%$ & $1 \mathrm{bl}$ \\
\hline P00 3249 & POS & $\begin{array}{l}\text { POS } \\
\text { Focal }\end{array}$ & POS & NEG & POS & NEG & NEG & NEG & $<2 \%$ & $1 \mathrm{bl}$ \\
\hline P11 1978 & POS & $\begin{array}{l}\text { POS } 1 \mathrm{bl} \\
\text { NEG } 2 \text { bl }\end{array}$ & POS & POS & POS & $\begin{array}{l}\text { POS } \\
\text { focal } 1 \text { bl; } \\
\text { NEG } 2 \\
\text { bl }\end{array}$ & NEG & NEG & $<2 \%$ & $3 \mathrm{bl}$ \\
\hline C12 1733 & NP & POS & POS & NP & POS & NEG & NEG & NEG & $<2 \%$ & $1 \mathrm{bl}$ \\
\hline C15 1962 & POS & POS & POS & POS & POS & NEG & NEG & NP & $<2 \%$ & $2 \mathrm{bl}$ \\
\hline $\begin{array}{l}\text { C15 7785 } \\
(\text { C15-1962) }\end{array}$ & POS & POS & $\begin{array}{l}\text { POS } \\
1 \mathrm{bl} ; \\
\mathrm{NEG} \\
1 \mathrm{bl}\end{array}$ & $\begin{array}{l}\text { POS } \\
1 \mathrm{bl} ; \\
\mathrm{NEG} \\
1 \mathrm{bl}\end{array}$ & POS & NEG & $\begin{array}{l}\text { POS focal } \\
1 \mathrm{bl}\end{array}$ & NEG & $<2 \%$ & $2 \mathrm{bl}$ \\
\hline P16 5242 & POS & $\begin{array}{l}\text { POS } 1 \mathrm{bl} \\
\text { NEG } 2 \mathrm{bl}\end{array}$ & POS & POS & POS & NEG & NEG & NEG & $8 \%$ & $3 \mathrm{bl}$ \\
\hline C18 113 & POS & NEG & POS & POS & POS & NEG & NEG & NEG & $<2 \%$ & $1 \mathrm{bl}$ \\
\hline
\end{tabular}

POS: positive; NEG: negative; NP: the exam was not performed; bl: block.

(Fig. 2C). Areas formed by granulation tissue and multinucleated giant cells containing cholesterol crystals were observed in two cases. Hemorrhagic foci and cell degeneration were observed in all cases, and fibrosis in four cases, with varying intensity. Eosinophilic granules, intra or extracellular, were observed in two cases and were positive to staining by PAS in one case and negative in another.

There were no significant histological changes in the pancreatic parenchyma adjacent to the neoplasms.

The immunohistochemical assay confirmed the diagnosis of SPNP by the positivity of the neoplastic cells, to the anti-beta-catenin antibodies in nuclear and cytoplasmic locations (Fig. 3A), the anti-CD99 of cytoplasmic granular pattern Fig.3B), the anti-CD-10 in cytoplasmic location Fig. 3C), the anti-progesterone receptor in nuclear location (Fig. 3D), and by the negativity to anti-E-cadherin, which are considered the main markers of this neoplasm (Table 3). The proliferative index assessed by the nuclear reaction in the neoplastic cells, with the anti-KI67 antibody, was lower than $2 \%$ in three cases and $8 \%$ in one case. This also presented a high mitotic index (six mitosis/ ten fields of large magnification) and is in regular outpatient monitoring since 2016, so far, uneventfully (Table 3 and Figure 3).

\section{CONCLUSION}

Solid pseudopapillary neoplasms of the pancreas have a heterogeneous pattern regarding their macroscopic, microscopic, immunophenotypic, and molecular aspects, as evidenced both in the bibliographical review, as in the cases studied. The histopathological diagnosis is guided by the presence of solid and pseudopapillary areas; however, the immunohistochemistry assists in the differential diagnosis with other pancreatic neoplasms, mainly by the aberrant nuclear expression of beta-catenin, associated to the lack of membrane expression of E-cadherin, the typical perinuclear granular marking of CD99, and CD10 positivity. Molecular biology is still poorly understood, although many studies on the subject have been published. Although rare and having, in most patients, good prognosis and excellent response to surgical treatment, it is a neoplasia that, due to its enigmatic cell origin and its morphological and molecular heterogeneity, encourages the search for a better understanding of its biology.

\section{Author Contribution}

Vera Lucia Chagas wrote the manuscript, and all authors reviewed it and made contributions. 


\section{RESUMO}

OBJETIVO: Fazer revisão da literatura e do diagnóstico histopatológico convencional de rotina e de imuno-histoquímica dos casos diagnosticados da neoplasia sólida pseudopapilar do pâncreas (NSPP).

MÉTODOS: A revisão da literatura foi feita utilizando as bases de dados PubMed e Google Scholar, por meio do histórico, aspectos clínicos e métodos de diagnóstico da NSPP. A revisão dos casos de NSPP diagnosticados no Hospital Universitário Clementino Fraga Filho da UFRJ foi feita no período de 1997 a 2018.

RESULTADOS: A heterogeneidade fenotípica intratumoral da NSPP foi evidenciada nos casos estudados, levando-se em conta os padrões macroscópicos, microscópicos e imuno-histológicos.

CONCLUSÕES: O conjunto de resultados evidencia a importância do exame de vários fragmentos obtidos de regiões distintas das neoplasias, uma vez que nem todos eles apresentam as mesmas alterações moleculares.

PALAVRAS-CHAVE: Pâncreas. Neoplasia sólida pseudopapilar.

\section{REFERENCES}

1. Igbinosa O. Pseudopapillary tumor of the pancreas. An algorithmic approach OP. 2011 May 6;12(3):262-5.

2. Hruban RH, PitmanMB, Klimstra DS. Solid Pseudopapillary Neoplasms. In: Atlas of Tumor Pathology. Fourth series. Fascicle 6. Washington DC, USA SArmed Forces Institute of Pathology;2007:231-50. 2007. 231 p.

3. A-Cienfuegos J, Lozano MD, Rotellar F, Martí P, Pedano N, Arredondo J, et al. Solid pseudopapillary tumor of the pancreas (SPPT). Still an unsolved enigma. Rev Esp Enferm Dig. 2010 Dec;102(12):722-8.

4. Martin RCG, Klimstra DS, Brennan MF, Conlon KC. Solid-pseudopapillary tumor of the pancreas: a surgical enigma? Ann Surg Oncol. 2002 Feb;9(1):35-40.

5. Klöppel G, Hrubam R, Klimstra, DS, Maitra A, Morohoshi T, Notohara K, et al. Solid-pseudopapillary neoplasm of the pancreas. In: WHO Classification of Tumors of the Digestive System. 4th ed. Lyon, France: International Agency for Research on Cancer; 2010.

6. Nguyen NQ, Johns AL, Gill AJ, Ring N, Chang DK, Clarkson A, et al. Clinical and immunohistochemical features of 34 solid pseudopapillary tumors of the pancreas. | Gastroenterol Hepatol. 2011 Feb;26(2):267-74.

7. Ye J, Ma M, Cheng D, Yuan F, Deng X, Zhan Q, et al. Solid-pseudopapillary tumor of the pancreas: clinical features, pathological characteristics, and origin. J Surg Oncol. 2012 Nov;106(6):728-35

8. Santini D, Poli F, Lega S. Solid-papillary tumors of the pancreas: histopathology. JOP. 2006 Jan 11;7(1):131-6.

9. Balercia G, Zamboni G, Bogina G, Mariuzzi GM. Solid-cystic tumor of the pancreas. An extensive ultrastructural study of fourteen cases. I Submicrosc Cytol Pathol. 1995 Jul;27(3):331-40.

10. Calvani I, Lopez P, Sarnacki S, Molina T], Gibault L, Fabre M, et al. Solid pseudopapillary neoplasms of the pancreas do not express major pancreatic markers in pediatric patients. Human Pathology. 2019 Jan;83:29-35.

11. Khaniya S, Shakya VC, Koirala R. Solid pseudopapillary tumor in an ectopic pancreas: an unusual presentation. I Surg Case Rep. 2017 Mar;2017(3):rjx050.

12. Zhu H, Xia D, Wang B, Meng H. Extrapancreatic solid pseudopapillary neoplasm: Report of a case of primary retroperitoneal origin and review of the literature. Oncol Lett. 2013 May;5(5):1501-4.

13. Walter T, Hommell-Fontaine |, Hervieu V, Adham M, Poncet G, Dumortier | et al. Primary malignant solid pseudopapillary tumors of the gastroduodenal area. Clin Res Hepatol Gastroenterol. 2011 Mar;35(3):227-33.

14. Gahlot GPS, Mridha AR, Sable M, Sharma MC, Pramanik R, Kumar L. Solid pseudopapillary neoplasm of the ovary with metastases to the omentum and regional lymph nodes. Indian | Pathol Microbiol. 2016 Sep;59(3):348-50.

15. Kosmahl M, Seada LS, Jänig U, Harms D, Klöppel G. Solid-pseudopapillary tumor of the pancreas: its origin revisited. Virchows Arch. 2000 May;436(5):473-80

16. Vassos N, Agaimy A, Klein P, Hohenberger W, Croner RS. Solid-pseudopapillary neoplasm (SPN) of the pancreas: case series and literature review on an enigmatic entity. Int J Clin Exp Pathol. 2013;6(6):1051-9.

17. Buetow PC, Buck JL, Pantongrag-Brown L, Beck KG, Ros PR, Adair CF. Solid and papillary epithelial neoplasm of the pancreas: imaging-pathologic correlation on 56 cases. Radiology. 1996 Jun;199(3):707-11.

18. Rocca R, Daperno M, Crocellà L, Lavagna A, Salvetto M. [Endoscopic ultrasound-fine needle aspiration (EUS-FNA) for pancreatic lesions: effectiveness in clinical practice]. Minerva Med. 2007 Aug;98(4):339-42.

19. Reindl BA, Lynch DW, Jassim AD. Aggressive variant of a solid pseudopapillary neoplasm: a case report and literature review. Arch Pathol Lab Med. 2014 Jul;138(7):974-8.

20. Serra S, Chetty R. Revision 2: an immunohistochemical approach and evaluation of solid pseudopapillary tumour of the pancreas. J Clin Pathol. 2008 Nov;61(11):1153-9.

21. Guo $Y$, Yuan F, Deng H, Wang H-F, Jin X-L, Xiao J-C. Paranuclear dotlike immunostaining for CD99: a unique staining pattern for diagnosing solid-pseudopapillary neoplasm of the pancreas. Am J Surg Pathol. 2011 Jun;35(6):799-806.

22. Notohara K, Hamazaki S, Tsukayama C, Nakamoto S, Kawabata K, Mizobuchi K, et al. Solid-pseudopapillary tumor of the pancreas: immunohistochemical localization of neuroendocrine markers and CD10. Am I Surg Pathol. 2000 Oct;24(10):1361-71.

23. Abraham SC, Klimstra DS, Wilentz RE, Yeo C), Conlon K, Brennan M, et al. Solid-pseudopapillary tumors of the pancreas are genetically distinct from pancreatic ductal adenocarcinomas and almost always harbor beta-catenin mutations. Am | Pathol. 2002 Apr;160(4):1361-9.

24. Chagas VLA, Ribeiro B dos SP, Mota e Silva MS, Forny DN, Rosman FC, Carvalho M da G da C. Epigenetics of Solid Pseudopapillary Neoplasm of the Pancreas. JOP. 2018;19(4):223-7.

25. Chagas VLA, Santos MDM, de Saldanha da Gama Fischer |, dos Santos Paiva Ribeiro B, Rosman FC, Carvalho PC, et al. A Molecular Study of Solid Pseudopapillary Neoplasm of the Pancreas in a Pediatric Patient. International Journal of Clinical Pediatrics. 2018;7(4):63-8. 